\title{
INFLUENCE OF NUT RAW MATERIAL PROCESSING PRODUCTS ON TECHNOLOGICAL PROPERTIES OF WHEAT FLOUR
}

\author{
E. Shidakova-Kamenyuka, A. Novik, S. Oliinyk, A. Zaparenko \\ Kharkiv State University of Food Technology and Trade
}

\begin{tabular}{|c|c|}
\hline Key words: & ABSTR \\
\hline $\begin{array}{l}\text { Wheat flour } \\
\text { Products of processing } \\
\text { Nut raw material } \\
\text { Walnut } \\
\text { Pine nut } \\
\text { Technological properties }\end{array}$ & $\begin{array}{l}\text { The influence of nut raw material processing products } \\
\text { (dietary additives "Pine nuts oilcake" and "Walnut oilcake") } \\
\text { on the quality indices of gluten and structural and } \\
\text { mechanical properties of wheat dough was investigated. It } \\
\text { was determined that introducing additives in the amount of } \\
5.0 . .20 .0 \% \text { by weight of flour helps to strengthen gluten, }\end{array}$ \\
\hline $\begin{array}{l}\quad \text { Article history: } \\
\text { Received } 12.05 .2017 \\
\text { Received in revised form } \\
05.06 .2017 \\
\text { Accepted } 21.06 .2017\end{array}$ & $\begin{array}{l}\text { reduce its yield and decrease its hydration capacity. At the } \\
\text { same time, an improvement in water-absorbing capacity of } \\
\text { the dough with additives, an increase in the duration of its } \\
\text { formation, and an increase in the degree of liquefaction due } \\
\text { to mechanical processing were revealed. The influence of }\end{array}$ \\
\hline $\begin{array}{l}\text { Corresponding author: } \\
\text { A. Novik } \\
\text { E-mail: } \\
\text { anna.novik.82@ukr.net }\end{array}$ & $\begin{array}{l}\text { nut raw material processing products on the technological } \\
\text { properties of wheat flour should be taken into account when } \\
\text { developing recipes and substantiating the parameters of } \\
\text { flour production technologies with the use of the mentioned } \\
\text { additives. }\end{array}$ \\
\hline
\end{tabular}

DOI: $10.24263 / 2225-2924-2017-23-4-24$

\section{ВПЛИВ ПРОДУКТІВ ПЕРЕРОБКИ ГОРІХОВОЇ СИРОВИНИ НА ТЕХНОЛОГІЧНІ ВЛАСТИВОСТІ БОРОШНА ПШЕНИЧНОГО}

\section{О.Г. Шидакова-Каменюка, Г.В. Новік, С.Г. Олійник, Г.В. Запаренко}

Харківський державний університет харчування та торгівлі

У статті досліджено вплив продуктів переробки горіхової сировини (дієтичних добавок «Шрот кедрового горіха» та «Шрот греиького горіха») на показники якості клейковини й структурно-механічні властивості пшеничного тіста. Встановлено, що внесення добавок у кількості 5,0...20,0\% від маси борошна сприяє зміцненню клейковини, зменшенню ї̈ виходу та зниженню гідратаційної здатності. Разом з тим виявлено покращення водопоглинальної здатності тіста з добавками, подовження тривалості його утворення та підвищення ступеня розрідження під дією механічної обробки. Вилив продуктів переробки горіхів на технологічні властивості пшеничного борошна необхідно враховувати під час розроблення рецептур та обтрунтування параметрів технологій борошняної продукиії з використанням зазначених добавок. 
Ключові слова: борошно пшеничне, продукти переробки, горіхова сировина, грещький горіх, кедровий горіх, технологічні властивості

Постановка проблеми. Сучасні раціони харчування населення України характеризуються незбалансованістю за біологічно цінними харчовими нутрієнтами, що викликає необхідність збагачення найбільш вживаних продуктів харчування на ці складові. Перспективним об'єктом для модифікації 3 точки зору коригування хімічного складу є борошняні вироби, які посідають важливе місце в раціоні сучасної людини. Збагачення зазначених продуктів можливе за рахунок використання в їх технологіях різноманітної рослинної сировини, зокрема побічної продукції олійно-жирової промисловості. Тісто уявляє собою складну полідисперсну систему, властивості якої значною мірою залежать від характеристик сировини, що входить до ії складу. Одним 3 основних рецептурних компонентів пшеничного тіста $€$ борошно. Внесення додаткової сировини може мати певний вплив на технологічні властивості борошна, які значною мірою зумовлюють якість напівфабрикатів і готових виробів.

Нами запропоновано для покращення хімічного складу борошняних виробів використовувати побічну продукцію, отриману після вилучення олії 3 такої нетрадиційної для олісекстракційного виробництва сировини, як горіхи. Для обгрунтування можливості використання продуктів переробки горіхів дієтичних добавок «Шрот кедрового горіху» (ШКГ) та «Шрот грецького горіху» (ШГГ) - у технологіях борошняної продукції вважали доцільним вивчення їх впливу на технологічні властивості пшеничного борошна.

Аналіз останніх досліджень і публікацій. Вивченню впливу побічної продукції олійно-жирової промисловості (макух і шротів 3 насіння льону, розторопші; зародків кукурудзи, вівса та пшениці тощо) на технологічні властивості пшеничного борошна та структурно-механічні властивості тіста присвячені праці [1-4]. Дослідники відзначають, що ступінь такого впливу значною мірою залежить від розміру часток добавок, їх кількості, хімічного складу тощо.

Попередній аналіз хімічного складу ШКГ і ШГГ [5] показав, що вони містять 38,6 и $33,6 \%$ білків, 11,2 и $15,4 \%$ жирів та 45,9 и $45,2 \%$ вуглеводів, в тому числі близько $16,0 \%$ крохмалю та 18,8 та $11,0 \%$ харчових волокон відповідно. За вмістом крохмалю досліджувані зразки майже не відрізняються, але крохмаль ШКГ в основному представлений амілозою, а ШГГ амілопектином. Також до складу зазначених продуктів переробки горіхової сировини входить значна кількість дубильних речовин (1380 та 4270 мг/100 г відповідно) та моно- й олігоцукридів (11,2 та $18,8 \%)$. Також були визначені функціонально-технологічні властивості добавок. Відзначено, що водоутримувальна здатність ШКГ та ШГГ вища порівняно з борошном пшеничним вищого сорту у 2,7 та 2,9 раза відповідно. Також встановлено, що ШКГ та ШГГ характеризуються вищим, ніж у борошна пшеничного показником активності $\alpha$-амілази - в 2,3 та 3,8 раза відповідно.

Особливості хімічного складу ШКГ та ШГГ, зокрема, наявність у них значної кількості поліненасичених жирних кислот, харчових волокон, ду- 
бильних речовин і моно- й олігоцукридів, висока активність $\alpha$-амілази будуть зумовлювати певну взаємодію добавок з борошном у разі їх використання в технологіях борошняної продукції.

Мета дослідження: визначення впливу продуктів переробки горіхової сировини - дієтичної добавки «Шрот кедрового горіху» (ШКГ) та дієтичної добавки «Шрот грецького горіху» (ШГГ) - на технологічні властивості борошна пшеничного.

Викладення основних результатів дослідження. Об'єкт досліджень були середне за силою борошно пшеничне вищого сорту та суміші борошна та добавок, у яких вміст ШКГ та ШГГ становив 5, 10, 15 та 20\%. Вплив добавок на технологічні властивості борошна оцінювали за зміною показників кількості та якості клейковини, а також за фізичними та структурно-механічними властивостями тіста. Вміст сирої та сухої клейковини визначали ваговим методом. Якість клейковини встановлювали за показниками розтяжності, пружності на приладі ІДК-1, розпливання кульки клейковини протягом 180 хв та гідратаційної здатності за стандартними методиками [6]. Фізичні та структурно-механічні властивості тіста визначали за допомогою приладів альвеограф Chopin [7], фаринограф Brabender [8]. Показник «число падіння» встановлювали з використанням приладу Falling Number [9].

Результати дослідження впливу продуктів переробки горіхової сировини на вміст і властивості клейковини борошна пшеничного представлено в табл. 1.

Таблиия 1. Вплив продуктів переробки горіхової сировини на вміст і властивості клейковини борошна пшеничного $(n=3 ; p \leq 0,95)$

\begin{tabular}{|c|c|c|c|c|c|c|}
\hline \multirow{2}{*}{ Зразок } & $\begin{array}{c}\text { Дозу- } \\
\text { вання } \\
\text { добавки, } \\
\%\end{array}$ & $\begin{array}{c}\text { Вміст сирої } \\
\text { клейко-вини, } \\
\%\end{array}$ & $\begin{array}{c}\text { Вміст сухої } \\
\text { клейко- } \\
\text { вини, \% }\end{array}$ & $\begin{array}{c}\text { Гідрата- } \\
\text { ційна здат- } \\
\text { ність, \% }\end{array}$ & $\begin{array}{c}\text { Пружність, } \\
\text { од. прил. } \\
\text { ІДК }\end{array}$ & $\begin{array}{c}\text { Розтяж- } \\
\text { ність, } \\
\text { см }\end{array}$ \\
\hline $\begin{array}{c}\text { без добавки } \\
\text { (контроль) }\end{array}$ & 0 & 29,9 & 10,4 & 186 & 80 & 13 \\
\hline \multirow{5}{*}{ з ШКГ } & 5,0 & 29,1 & 10,3 & 183 & 75 & 10,5 \\
\cline { 2 - 7 } & 10,0 & 28,2 & 10,2 & 177 & 70 & 9,5 \\
\cline { 2 - 7 } & 15,0 & 25,9 & 9,5 & 171 & 65 & 8,5 \\
\cline { 2 - 7 } & 20,0 & 22,0 & 8,2 & 168 & 60 & 7,5 \\
\hline \multirow{5}{*}{ з ШГГ } & 5,0 & 27,6 & 10,0 & 175 & 73 & 10,0 \\
\cline { 2 - 7 } & 10,0 & 26,2 & 9,6 & 172 & 69 & 8,5 \\
\cline { 2 - 7 } & 15,0 & 22,2 & 8,2 & 169 & 63 & 5,5 \\
\cline { 2 - 7 } & 20,0 & 17,9 & 6,7 & 165 & 57 & 4,5 \\
\hline
\end{tabular}

Встановлено, що внесення ШКГ у кількості 5,0 та 10,0\% майже не впливає на вміст сирої та сухої клейковини - зміни значень цих показників знаходяться в межах похибки експерименту. У разі збільшення дозування ШКГ до 15 та 20\% кількість сирої та сухої клейковини знижується відносно контрольного зразка на 13,4 та 26,4\%. Відмічається, що ШГГ має більш суттєвий вплив на значення цих показників За умов внесення 20\% цієї добавки зменшення кількості сирої та сухої клейковини становить 40,1 та 35,6 \% відповідно. 
На наш погляд, зменшення кількості клейковини можна пояснити декількома чинниками. По-перше, досліджувані продукти переробки горіхової сировини містять жири (у ШКГ - 11,2\%, у ШГГ - 15,4\%), які розподіляючись на поверхні білкових молекул екранують їх гідрофільні сполуки та обмежують набрякання та структурування білкових міцел. Як наслідок, білки, що не набрякли, відмиваються разом 3 крохмалем та іншими компонентами. У зв'язку з тим, що до складу ШГГ входить більша кількість жирів, ніж до складу ШКГ, тенденція до зниження кількості клейковини у зразках з цією добавкою більш виражена. По-друге, до складу добавок входить значна кількість некрохмальних полісахаридів, які володіють високою водопоглинальною здатністю, внаслідок чого утворюють конкуренцію біополімерам борошна в поглинанні вологи. Також вони здатні утворювати білок-полісахаридні комплекси з білковими речовинами борошна, які не утворюватимуть клейковину.

Вищезазначене також пояснює зниження показника гідратаційної здатності клейковини. Зокрема, за умов максимально досліджуваного дозування ШКГ та ШГГ гідратаційна здатність клейковин них білків зменшується на 9,7 та 11,3\% порівняно з контрольним зразком.

Розтяжність зразків за умов підвищення дозування добавок зменшується (для зразків з ШКГ — на 19,2...42,3\%, для зразків з ШГГ — на 23,1...65,4\%), що зумовлене порушенням цілісності клейковинного каркасу внаслідок розподілення частинок ШКГ та ШГГ між частинками борошна.

Дослідження показників пружності (табл. 1) та розпливання кульки клейковини (рис. 1) свідчать про ії зміцнення.
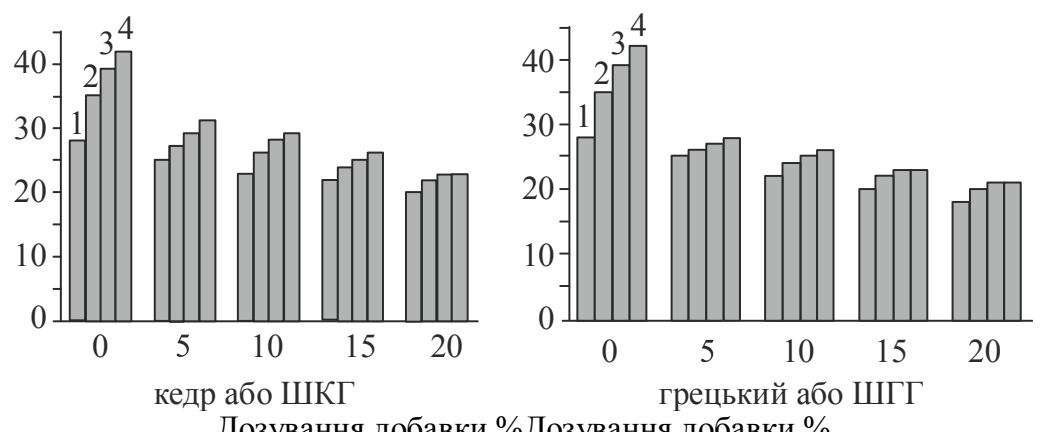

Дозування добавки,\%Дозування добавки,\%

а)б)

Рис. 1. Вплив ШКГ (а) та ШГГ (б) на розпливання кульки клейковини через:

$1-0$ хв, $2-60$ хв; $3-120$ хв; $4-180$ хв

Зокрема, у разі внесення до борошняної суміші ШКГ у кількості 5,0...20,0\% відмічається зниження значення показнику пружності клейковини на $6,3 . \ldots 9,7 \%$ відносно контрольного зразка. Для систем з аналогічним вмістом ШГГ зниження значення цього показника становить $8,8 \ldots .28,8 \%$.

Встановлено, що показник розпливання кульки клейковини через 180 хв у зразках з ШКГ та ШГГ зменшується порівняно з контрольним у 1,4...1,8 та 1,5 та 2,0 рази відповідно. 
Зміцнюючий ефект на клейковину можуть мати наявні у складі досліджуваних продуктів переробки горіхів фенольні сполуки, які здатні утворювати комплекси 3 білками [10]. Також жири добавок в основному представлені поліненасиченими жирними кислотами, що під час окислення утворюють перекисні сполуки. Пероксиди та гідропероксиди сприяють окисленню сульфгідрильних груп білкових молекул з утворенням дисульфідних зв'язків, які зміцнюють внутрішньомолекулярну структуру клейковини та сприяють іiі ущільненню [11]. Вищій вміст жирів і фенольних сполук у ШГГ сприяє тому, що його зміцнювальний ефект на клейковинні білки є більш вираженим.

Отримані дані корелюють з результатами досліджень реологічних властивостей зразків тіста 3 додаванням вторинної горіхової сировини, отриманих на альвеографі (табл. 2).

Відмічається неможливість дослідження зразків тіста 3 вмістом добавок $20 \%$ від маси борошна за рахунок обмеження технічних характеристик пристрою, що може бути зумовлене тим, що харчові волокна ускладнюють утворення еластичного клейковинного каркасу.

Встановлено, що внесення ШКГ у кількості 5,0\% не впливає на показник пружності тіста. Збільшення дозування ШКГ до 10 та 15\% сприяє підвищенню значення цього показника в 1,4 та 1,7 раза, розтяжність дослідних зразків при цьому знижується в 1,8 та 2,1 раза відповідно.

Відзначається, що ШГГ має більш суттєвий вплив на реологічні властивості тіста.

Таблиия 2. Результати розшифровок альвеограм досліджуваних зразків тіста $(n=3 ; p \leq 0,05)$

\begin{tabular}{|c|c|c|c|c|c|c|}
\hline Зразок & $\begin{array}{c}\text { Дозу- } \\
\text { вання } \\
\text { добавки, } \\
\text { \% }\end{array}$ & $\begin{array}{c}\text { Пружність } \\
(P), \text { мм }\end{array}$ & $\begin{array}{c}\text { Розтяжність } \\
(L), \text { мм }\end{array}$ & $\begin{array}{c}\text { Збалансова- } \\
\text { ність тіста } \\
(P / L)\end{array}$ & $\begin{array}{c}\text { Питома робота } \\
\text { пружної } \\
\text { деформації }(W), \\
\text { о.а. }\end{array}$ & $\begin{array}{c}\text { Індекс } \\
\text { еластич- } \\
\text { ності, \% }\end{array}$ \\
\hline $\begin{array}{c}\text { Без добавки } \\
\text { (контроль) }\end{array}$ & 0 & 54 & 108 & 0,5 & 190 & 57 \\
\hline \multirow{4}{*}{ Із ШКГ } & 5,0 & 56 & 83 & 0,7 & 196 & 52 \\
\hline & 10,0 & 77 & 61 & 1,5 & 200 & 49 \\
\hline & 15,0 & 94 & 51 & 1,8 & 213 & 40 \\
\hline & 20,0 & - & - & - & - & - \\
\hline \multirow{4}{*}{ Із ШГГ } & 5,0 & 65 & 78 & 1,0 & 229 & 57 \\
\hline & 10,0 & 117 & 66 & 1,8 & 262 & 56 \\
\hline & 15,0 & 173 & 42 & 4,1 & 320 & 55 \\
\hline & 20,0 & - & - & - & - & - \\
\hline
\end{tabular}

За умов дозування цієї добавки у досліджуваному інтервалі концентрацій показник пружності тіста зростає у $1,2 \ldots 3,2$ раза, а показник розтяжності тіста знижується у $1,4 \ldots 2,6$ раза відповідно. Як наслідок, відбувається підвищення показнику збалансованості тіста порівняно 3 контролем в 3,6 та 8,2 раза за максимальної кількості ШКГ та ШГГ. Зростання питомої роботи пружної деформації (W) у зразках з вторинною горіховою сировиною також свідчить про підвищення сили борошна. 
Водопоглинальну здатність борошняних сумішей, консистенцію, час утворення, стійкість і розрідження досліджуваних зразків тіста визначено на фаринографі Brabender. Встановлено, що внесення досліджуваної вторинної горіхової сировини сприяє підвищенню водопоглинальної здатності тіста (табл. 3).

Зокрема, значення цього показника для тістових систем з додаванням 15 та $20 \%$ ШКГ перевершують контрольний зразок на 5,3 та 6,7\%, а для систем 3 ШГГ — на $6,2 \ldots 8,8 \%$ відповідно. Така динаміка пояснюється більш високими порівняно з борошном водоутримувальними властивостями ШКГ та ШГГ (у 2,7 та 2,9 раза відповідно).

Таблиия 3. Результати розшифровок фаринограм досліджуваних зразків тіста $(n=3 ; p \leq 0,05)$

\begin{tabular}{|c|c|c|c|c|c|}
\hline \multirow{2}{*}{ Зразок } & $\begin{array}{c}\text { Дозування } \\
\text { добавки, } \\
\%\end{array}$ & $\begin{array}{c}\text { Водопогли- } \\
\text { нальна } \\
\text { здатність, \% }\end{array}$ & $\begin{array}{c}\text { Час утворення, } \\
\tau \times \text { х } 60^{-1} \mathrm{c}\end{array}$ & $\begin{array}{c}\text { Стійкість, } \\
\tau \times 0^{-1} \mathrm{c}\end{array}$ & $\begin{array}{c}\text { Ступінь } \\
\text { розрідження, } \\
\text { од.ф }\end{array}$ \\
\hline $\begin{array}{c}\text { Без добавки } \\
\text { (контроль) }\end{array}$ & 0 & 62,3 & 2,5 & 4,5 & 65 \\
\hline \multirow{5}{*}{ Із ШКГ } & 5,0 & 62,9 & 2,9 & 4,2 & 100 \\
\cline { 2 - 6 } & 10,0 & 63,9 & 3,4 & 3,9 & 130 \\
\cline { 2 - 6 } & 15,0 & 65,6 & 3,8 & 2,8 & 145 \\
\cline { 2 - 6 } & 20,0 & 66,5 & 4,2 & 2,5 & 155 \\
\hline \multirow{5}{*}{ Із ШГГ } & 5,0 & 64,4 & 2,8 & 3,9 & 120 \\
\cline { 2 - 6 } & 10,0 & 65,3 & 3,1 & 3,1 & 145 \\
\cline { 2 - 6 } & 15,0 & 66,2 & 3,4 & 2,7 & 170 \\
\cline { 2 - 6 } & 20,0 & 67,8 & 3,8 & 1,4 & 190 \\
\hline
\end{tabular}

Час утворення тіста 3 додаванням ШКГ та ШГГ збільшується у 1,2 ..1,7 та $1,1 \ldots 1,5$ раза відповідно. Більш виражена тенденція до зміни цього показника характерна для ШКГ. Можливо, це пов'язано з тим, що висока водопоглинальна здатність ШКГ зумовлена наявністю у його складі значної кількості харчових волокон, які потребують більше часу для повної гідратації. У той час, як гідрофільні властивості ШГГ пов'язані зі значним вмістом амілопектину, який потребує менше часу для набухання.

Також, використання ШКГ та ШГГ сприяє зниженню стійкості тіста (в $1,1 \ldots 1,8$ та $1,2 \ldots 3,2$ раза відповідно) та підвищенню ступеня його розрідження під дією механічної обробки (в $1,5 \ldots .2,4$ та $1,8 \ldots .2,9$ раза відповідно). Отримані результати можна пояснити дегідратуючою здатністю цукрів добавок (вміст моноцукрів у ШГГ майже у 2 раза вище, ніж у ШКГ, що зумовлює уповільнення гідратації гідроколоїдів тіста) та більш високою порівняно 3 борошном активністю їх $\alpha$-амілаз (в 2,3 та 3,8 раза відповідно), що сприяє інтенсифікації гідролізу крохмалю. Отримані дані корелюють 3 результатами дослідження показника «число падіння» водно-борошняної суспензії 3 добавками (рис. 2).

Відмічено, що значення цього показника знижується із 300 с у контролі до 232 с у зразка з $20 \%$ ШКГ та до 215 с у зразка з таким самим вмістом ШГГ. 
Попередніми дослідженнями встановлено, що активність амілолітичних ферментів ШГГ в 1,7 раза вища, ніж у ШКГ, що зумовлює більш інтенсивне зниження показника «число падіння» у разі його внесення до водноборошняних суспензій.

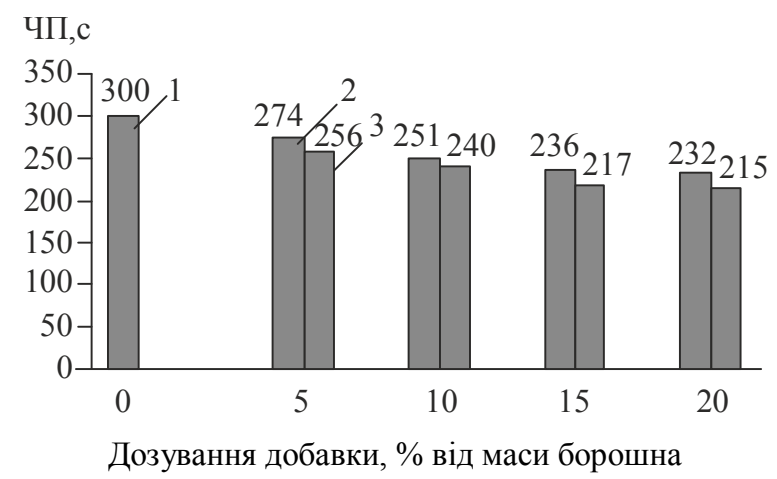

Рис. 2. Вплив добавок на показник «число падіння» пшеничного борошна: 1 - без добавок (контроль); 2 - 3 ШКГ; 3 - 3 ШГГ

Таким чином, внесення продуктів переробки горіхової сировини, а саме дієтичних добавок «Шрот кедрового горіха» $\mathrm{i}$ «Шрот грецького горіха» у кількості 5,0..20,0 \% від маси борошна, сприяє зміцненню клейковини пшеничного борошна, зниженню іiї виходу та має певний вплив на фізичні й структурно-механічні властивості пшеничного тіста, що необхідно враховувати під час розроблення рецептур та обгрунтування параметрів технологій борошняної продукції з використанням зазначених добавок.

\section{Висновки}

1. Встановлено, що внесення дієтичних добавок «Шрот кедрового горіха» та «Шрот грецького горіха» сприяє зменшенню виходу клейковини, знижує іiі гідратаційну здатність, що зумовлюється утворенням білок-полісахаридних комплексів між харчовими волокнами добавок і білками борошна. Виявлено зміцнюючий ефект добавок на клейковину, який проявляється у певних змінах фізичних та структурно-механічних властивостей тіста. Зміцнюючий ефект добавок зумовлений наявністю в них дубильних речовин і продуктів окислення жирів.

2. Відмічається покращення водопоглинальної здатності тіста $з$ добавками, подовження тривалості його утворення, зниження стійкості та підвищення ступеню розрідження під дією механічної обробки. Зазначене зумовлюється конкуренцією у поглинанні вологи між харчовими волокнами добавок i біополімерами борошна, дегідратуючою здатністю цукрів добавок та більш високою порівняно з борошном активністю їх $\alpha$-амілаз.

\section{Література}

1. Дробот B.I. Дослідження структурно-механічних властивостей тіста зі шротом льону / В.І. Дробот, О.П. Іжевська, Ю.В. Бондаренко // Хлібопекарська і кондитерська промисловість України. — 2015. — № 10(131). — С. 29-33. 
2. Цыганова T.B. Влияние шрота и масла расторопши на реологические свойтства теста / Т.В. Цыганова, Н.Г. Семенкина // 3-ий Междунар. Хлебопекарный Форум : [Материалы докл.]. - Москва, 2010. — С. 119-121.

3. Олейник С.Г. Влияние продуктов переработки зародышей овса и кукурузы на структурно-механические свойства теста из пшеничной муки / С.Г. Олейник, Г.В. Степанькова // Scientific Letters of Academic Society of Michal Baludansky. Словакия, 2014. - Вип. 2(5). - С. 76-80.

4. Кравченко O.I. Використання дієтичної добавки «Шрот зародків пшениці харчовий» для підвищення харчової цінності хліба / О.І. Кравченко, Г.М. Лисюк, С.Г. Олійник // Зб. наук. праць Одеської національної академії харчових виробництв. - Одеса : ОНАХТ, 2010. - C. $195-200$.

5. Шидакова-Каменюка О.Г. Перспективи використання шротів горіхової сировини для збагачення борошняних кондитерських виробів / О.Г. Шидакова-Каменюка, Г.В. Новік, К.Р. Касабова, О.І. Кравченко // Прогресивні техніка та технології харчових виробництв ресторанного господарства i торгівлі: Зб. наук. праць Харківського державного університету харчування та торгівлі. - Харків : ХДУХТ, 2015. — Вип. 2. C. $69-81$.

6. Лабораторний практикум з технології хлібопекарського та макаронного виробництв : навч. посібник / В.І. Дробот, Л.Ю. Арсеньєва, О.А. Білик [та ін.]. - Київ : Центр навч. літератури, 2006. - 341с.

7. Методичні рекомендації з оцінки якості зерна селекційного матеріалу / О.Ю. Леонов, І.А. Панченко, К.М. Скляревський [та ін.]. — Харків : Іститут рослинництва ім. В. Я. Юр'єва НААН України, 2011. — 70с.

8. ГОСТ ISO 5530-1-2013 Мука пшеничная. Физические характеристики теста. Ч. 1. : Определение водопоглощения и реологических свойств с применением фаринографа. [Введ. 2014-01-01]. - Москва : Стандарт-информ, 2014. - 16 с.

9. ГОСТ 27676-88 Зерно и продукты его переработки. Метод определения числа падения. — [Введ. 1990-07-01]. — Москва : Стандарт-информ, 2009. — 5 с.

10. Запрометов М.Н. Фенольные соединения. Распространение, метаболизм и функции в растениях / М.Н. Запрометов. - Москва : Наука, 1993. - 272 с.

11. Козьмина Н.П. Зерноведение (с основами биохимии растений) / Н.П. Козьмина, В.А. Гункин, Г.М. Суслянок. - Москва, 2006. - 464 с. 